\title{
Surface Analysis Study on ZIRLO Cladding Hulls Oxidized at Low Temperatures
}

\section{저온 산화된 ZIRLO 피복관의 표면분석 연구}

\author{
Min Ku Jeon*, Yong Taek Choi, Chang Hwa Lee, Kweon Ho Kang, and Geun Il Park \\ Korea Atomic Energy Research Institute, 111 Daedeok-daero 989, Yuseong-gu, Daejeon, Korea \\ 전민구*, 최용택, 이창화, 강권호, 박근일 \\ 한국원자력연구원, 대전광역시 유성구 대덕대로 989 번길 111
}

(Received August 28, 2014 / Revised September 19, 2014 / Approved September 22, 2014)

\begin{abstract}
Surface oxidation behavior of ZIRLO (ZIRconium Low Oxidation) hulls was investigated using an X-ray photoelectron spectroscopy (XPS) technique. The effects of oxidation time $\left(10-336 \mathrm{~h}\right.$ at $\left.500^{\circ} \mathrm{C}\right)$ and temperature $\left(400-700^{\circ} \mathrm{C}\right.$ for $\left.10 \mathrm{~h}\right)$ were studied. Deconvolution results of the hulls oxidized at $500^{\circ} \mathrm{C}$ revealed that a $\mathrm{ZrO}_{2}$ phase appeared after $24 \mathrm{~h}(11.86 \%)$, and an increase in the $\mathrm{ZrO}_{2}$ ratio was observed when the hulls were oxidized for $336 \mathrm{~h}$ (17.93\%). On the other hand, the $\mathrm{ZrO}$ phase which employed $5.68 \%$ in the $10 \mathrm{~h}$ oxidized sample disappeared when the oxidation time increased to $24 \mathrm{~h}$. The XPS results also showed that an increase in the oxidation temperature resulted in an increase in the ratio of $\mathrm{ZrO}$, which increased from 0 to $5.68,8.31$, and $9.16 \%$ when the oxidation temperature increased from 400 to 500,600 , and $700^{\circ} \mathrm{C}$, respectively. $\mathrm{ZrO}_{2}$ phase was observed only in the sample that was oxidized at $700^{\circ} \mathrm{C}$. The mechanism of $\mathrm{ZrO}$ formation was not conclusive, but it was suggested that a formation of hydroxide might have been accelerated at elevated temperatures leading to a formation of a $\mathrm{Zr}(\mathrm{OH})_{4}$ phase. The relationship between the surface oxidation status of the hulls oxidized at $500^{\circ} \mathrm{C}$ and their chlorination reaction feasibility was discussed, and it was suggested that the thickness of the oxide layer is an important parameter that determines the chlorination reaction feasibility.
\end{abstract}

Keywords: X-ray photoelectron spectroscopy, Cladding hull, ZIRLO, Oxidation, Chlorination

본 논문에서는 X선 광전자 분광법(X-ray photoelectron spectroscopy, XPS)을 이용하여 ZIRLO (ZIRconium Low Oxidation) 피복관의 표면 산화 거동을 연구하였다. 산화 시간 $\left(10-336\right.$ 시간, $\left.500^{\circ} \mathrm{C}\right)$ 및 산화 온도 $\left(400-700^{\circ} \mathrm{C}, 10\right.$ 시간)에 따른 산화 특성 변화를 관찰하였다. XPS peak 분석 결과, $500^{\circ} \mathrm{C}$ 에서 산화된 피복관의 산화 시간이 24 시간이 될 때 $\mathrm{ZrO}_{2}$ peak가 $11.86 \%$ 관 찰되었으며, 이후 산화 시간이 길어질수록 $\mathrm{ZrO}_{2}$ 의 비율이 $17.93 \%$ 까지 (336 시간) 증가하는 것이 확인되었다. 반면, 10 시간 산화된 피복관에서 $5.68 \%$ 존재하던 $\mathrm{ZrO}$ 상은 산화 시간이 24 시간으로 늘어남에 따라 사라지는 것이 관찰되었다. 산화 온 도 증가에 의한 영향 분석 결과에서는 산화 온도가 $400^{\circ} \mathrm{C}$ 에서 $500,600,700^{\circ} \mathrm{C}$ 로 증가할 때 $\mathrm{ZrO}$ 상의 비율이 $0 \%$ 부터 5.68 , $8.31,9.16 \%$ 로 증가하는 것이 확인되었다. 이 때, $\mathrm{ZrO}_{2}$ 상은 $700^{\circ} \mathrm{C}$ 에서 산화된 시료에서만 관찰되었다. $\mathrm{ZrO}$ 상의 형성 메커 니즘은 불명확하지만, 고온에서 공기 중의 수분과 $\mathrm{Zr}$ 의 반응으로 인해 $\mathrm{Zr}(\mathrm{OH})_{4}$ 상의 형성이 가속되는 것으로 예상된다. 본 논문에는 $500^{\circ} \mathrm{C}$ 에서 산화된 ZIRLO 피복관과 이들의 염소화 반응 특성에 대한 논의도 포함되었으며, 염소화 반응 진행 가능 성에 있어서 산화막의 두께가 중요한 역할을 하는 것으로 보여진다.

중심단어: 폐 피복관, 표면분석, ZIRLO, 산화, 염소화

* Corresponding Author.

Min Ku Jeon, Korea Atomic Energy Research Institute, E-mail: minku@kaeri.re.kr, Tel: +82-42-868-2435 


\section{Introduction}

Cladding hull waste is an interesting subject in the nuclear waste treatment field, owing to its large portion (about $25 \mathrm{wt} \%$ ) in used nuclear fuel (UNF) and high content of $\mathrm{Zr}$ (about 97wt\%) [1, 2]. Currently, acid washing and compaction techniques are widely employed to manage the cladding hull waste. The acid washing is a convenient method to remove residual UNF from the cladding hulls that are stuck on the inner surface, but it is also well known that the acid washing procedure is insufficient to classify the cladding hull waste as a low-level waste $[3,4]$. In addition, it was revealed that the radioactivity of ${ }^{94} \mathrm{Nb}$, which is one of the major radioactivation products of $\mathrm{Nb}$ contained in ZIRLO (ZIRconium Low Oxidation) cladding hull material, exceeds acceptance limit of the Wolsong LILW (Low and Intermediate Level Waste) disposal center (WLDC) of Korea [5]. Thus, a selective recovery of $\mathrm{Zr}$ from the cladding hull waste is an attractive approach to minimize the generation of mid-/high-level waste regardless of UNF treatment methods. The selective recovery of $\mathrm{Zr}$ is also considered as a pre-treatment of dry storage systems, because a separation of cladding hulls from nuclear materials can eliminate the risk of fractured cladding and handling issues during storage and transportation [1].

There are two technologies under research at the Korea Atomic Energy Research Institute (KAERI) for the selective recovery of $\mathrm{Zr}$ : chlorination and electro-refining techniques. The latter employs electrochemical reactions to dissolve and selectively recover metallic $\mathrm{Zr}$ by controlling an applied potential or current [6-8]. This technique has some advantages including recovery of $\mathrm{Zr}$ in its metallic form and relatively mild operation conditions, while the reaction rate, scale-up, and electrolyte treatment issues need verification. The chlorination process employs a simple chemical reaction between metallic $\mathrm{Zr}$ and chlorine gas to produce zirconium tetrachloride which sublimes at $331^{\circ} \mathrm{C}$. During the chlorination process, the purity of recovered $\mathrm{Zr}$ is determined by the operation temperature owing to a formation of volatile chlorides of other constituent metals such as niobium and tin [4]. Compared to the electro-refining process, it is suggested that the chlorination process is more convenient to control the reaction rate and scale-up, while a reduction of recovered $\mathrm{ZrCl}_{4}$ should be followed if it cannot be recycled during cladding hull production [1].

The chlorination process was previously demonstrated at the Institute of Research and Innovation (IRI, Japan) [9], KAERI (Korea) [10], and Oak Ridge National Laboratory (ORNL, USA) [1]. At the IRI, a recovery of Zr from Zircaloy-2 cladding hulls was successfully demonstrated in the presence of $\mathrm{Ni}$ and $\mathrm{Co}$, which are major sources of radioactivity of cladding hull waste [9]. At KAERI, Zircaloy-4 cladding hulls were employed for the chlorination reaction, and highly pure $\mathrm{ZrCl}_{4}(99.97 \mathrm{wt} \%$ ) was recovered without further heat treatments [10]. At the ORNL, an actual cladding hull (Zircaloy-2) of UNF was employed for the chlorination reaction, and high decontamination factors (> 1200 for total radiation) were reported [1]. It should be noted that the previous reports employed Zircaloy alloys for the chlorination process because they are major cladding materials stacked in reactor site pools. However, it is well known that nowadays ZIRLO is widely employed in pressurized water reactors as well as Zircaloy alloys. Tin $(\sim 1.5 \mathrm{wt} \%)$, iron $(\sim 0.2 \mathrm{wt} \%)$, and chromium $(\sim 0.1 \mathrm{wt} \%)$ are the major alloying elements in Zircaloy-4, while niobium $(\sim 1.0 \mathrm{wt} \%)$, tin $(\sim 1.0 \mathrm{wt} \%)$, and iron $(\sim 0.1 \mathrm{wt} \%)$ are alloyed with Zr for ZIRLO offering enhanced corrosion resistance over the Zircaloy alloys. The enhanced chemical characteristic of ZIRLO makes it worth verifying a feasibility of $\mathrm{Zr}$ recovery from ZIRLO cladding hulls through the chlorination method.

We previously reported that the surface oxidation status of Zircaloy-4 cladding material played a key role in determining the feasibility of the chlorination reaction [11]. An $\mathrm{X}$-ray photoelectron spectroscopic (XPS) result revealed that the Zircaloy- 4 hulls oxidized at $500^{\circ} \mathrm{C}$ for $5 \mathrm{~h}$, which was reactive to chlorine gas, contained $\mathrm{Zr}_{2} \mathrm{O}_{3}(83.0 \%)$ and $\mathrm{ZrO}(17.0 \%)$ phases on its surface, while the other one that 
was oxidized at $700^{\circ} \mathrm{C}$ for $5 \mathrm{~h} \mathrm{had} \mathrm{Zr}_{2} \mathrm{O}_{3}(69.4 \%)$ and $\mathrm{ZrO}_{2}$ $(30.6 \%)$ phases on its surface and was not reactive with chlorine gas [11]. Although the relationship between the surface oxidation status and chlorination reaction feasibility is not clear yet, it is obvious that the surface oxidation status should be considered as a key parameter in designing the chlorination process. In the case of ZIRLO, only one report was presented on the chlorination reaction behavior [12]. Interestingly, it was shown that the ZIRLO hulls oxidized at $500^{\circ} \mathrm{C}$ for various hours (from zero to $168 \mathrm{~h}$ ) exhibit significantly different chlorination reaction behaviors. Some reaction products were observed in the hulls oxidized for $24 \mathrm{~h}$, while no signs of reaction were observed in the $72 \mathrm{~h}$ oxidized hulls. Thus, it might be interesting to clarify what happened to the surface of the hulls when they were oxidized at different conditions.

\section{Experimental}

The surface oxidation status of the hulls was investigated using the XPS (Kratos AXIS Nova) technique. Monochromated Al $\mathrm{K}_{\alpha}(1486.76 \mathrm{eV})$ was employed to collect the spectra at $0^{\circ}$ between the sample surface normal and the analyzer lens. A pass energy of $40 \mathrm{eV}$ and step size of 50 $\mathrm{meV}$ were employed for the high-resolution regions scans. The charge compensation of the samples was performed during the measurement using a charge neutralizer. The measured binding energies were referenced with respect to C 1s peak at $284.8 \mathrm{eV}$. Deconvolution of the XPS peaks was performed using the XPS 4.1 software [13]. The effect of oxidation time on the surface oxidation status was studied by preparing $5 \mathrm{~cm}$-long ZIRLO hulls oxidized at $500^{\circ} \mathrm{C}$ for $10,24,72,168$, and $336 \mathrm{~h}$ under an air atmosphere. In addition, the effect of oxidation temperature was also investigated by oxidizing the ZIRLO hulls at 400, 600, and $700^{\circ} \mathrm{C}$ for $10 \mathrm{~h}$. Through this paper, the hull samples were denoted as 'ZIRLO-(oxidation temperature)-(oxidation time)' for convenience, and thus ZIRLO-500-72 means

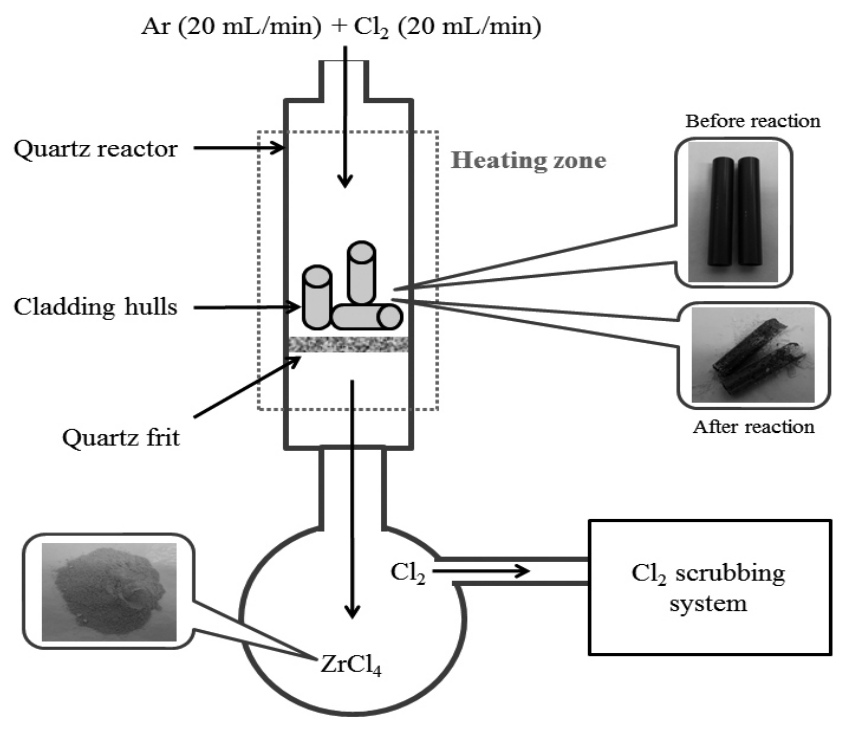

Fig. 1. Experimental set-up and pictures of reaction reactants and products for ZIRLO-500-10.

ZIRLO hulls oxidized at $500^{\circ} \mathrm{C}$ for $72 \mathrm{~h}$. In accordance with the surface oxidation status, the detailed results of our previous work [12] on the chlorination reaction behavior of ZIRLO hulls oxidized at $500^{\circ} \mathrm{C}$ for various periods (0$168 \mathrm{~h}$ ) were introduced in the present study. A previously reported experimental set-up was employed for the chlorination experiments [10]. Briefly, the reactor is a vertical quartz tube which has a quartz frit in the middle so that it can hold cladding hulls at the reaction zone while gases and volatile reaction products can pass through it. The chlorination reaction was performed at $380^{\circ} \mathrm{C}$ for $2 \mathrm{~h}$ while feeding argon and chlorine gases at a flow rate of $20 \mathrm{~mL} / \mathrm{min}$ for each gas. Experimental set-up of the chlorination reaction experiments is shown in Fig. 1.

\section{Results and Discussion}

Before getting started with the oxidation status analysis of the ZIRLO hulls, the relationship between an oxidation condition and a chlorination reaction behavior needs to be discussed, because it can help to clarify the relationship 
Table 1. A summary of the chlorination reaction experimental results including the results of previous work [12]. The experiments were performed at $380^{\circ} \mathrm{C}$ for $2 \mathrm{~h}$ under a flow of $20 \mathrm{~mL} \mathrm{~min}^{-1} \mathrm{Ar}$ and $20 \mathrm{~mL}$ $\min ^{-1} \mathrm{Cl}_{2}$

\begin{tabular}{ccccc}
\hline Samples & Reactant & Residue & Product & Weight loss \\
\hline ZIRLO-bare & $10.05 \mathrm{~g}$ & $4.34 \mathrm{~g}$ & $13.33 \mathrm{~g}$ & $56.8 \mathrm{wt} \%$ \\
\hline ZIRLO-500-10 & $10.07 \mathrm{~g}$ & $6.56 \mathrm{~g}$ & $7.66 \mathrm{~g}$ & $34.9 \mathrm{wt} \%$ \\
\hline ZIRLO-500-24 & $10.16 \mathrm{~g}$ & $6.57 \mathrm{~g}$ & $7.90 \mathrm{~g}$ & $35.3 \mathrm{wt} \%$ \\
\hline ZIRLO-500-72 & $10.09 \mathrm{~g}$ & $10.09 \mathrm{~g}$ & $0.00 \mathrm{~g}$ & $0.0 \mathrm{wt} \%$ \\
\hline ZIRLO-500-168 & $10.13 \mathrm{~g}$ & $10.13 \mathrm{~g}$ & $0.00 \mathrm{~g}$ & $0.0 \mathrm{wt} \%$ \\
\hline
\end{tabular}

between the oxidation status and chlorination reaction behavior. A summary of the chlorination reaction behavior is listed in Table 1, including the results of our previous work [12]. The pictures of reaction reactants and products for ZIRLO-500-10 are shown in Fig. 1. It is clear, at once, that an increase in the oxidation time reduces the reaction rate of the ZIRLO chlorination reaction. It is interesting to observe that a significant change in the weight loss was observed between ZIRLO-bare and ZIRLO-500-10, while the difference between ZIRLO-500-10 and ZIRLO-500-24 is negligible. In addition, it was found that ZIRLO-500-72 is not reactive with chlorine gas meaning that these hulls were completely protected by oxide layers from chlorine gas. The weight loss behavior of ZIRLO hulls oxidized for $24 \mathrm{~h}$ is somewhat different from the case of Zircaloy-4 [11]: weight loss values for the Zircaloy-bare and Zircaloy-500-24 cases were 54.1 and 50.7\%, respectively, meaning that the protective role of the surface oxide layer is more significant in the ZIRLO hulls. As the previous study [11] lacks the chlorination reaction behavior of the hulls oxidized for 72 and $168 \mathrm{~h}$, an additional experiment was performed for Zircaloy-500-168 for comparison, and no signs of reaction were observed at the identical reaction condition of this study. These results reveal that the oxide layers formed on the surface of ZIRLO hulls impact more influence on the chlorination reaction than the oxide layers of Zircaloy-4 hulls, while both the ZIRLO and Zircaloy-4 hulls are completely protected from chlorine gas when they
Table 2. Oxide thickness values of ZIRLO and Zircaloy-4 alloys calculated using oxide thickness rate constant values offered by Natesan and Soppet [14]

\begin{tabular}{|c|c|c|c|c|c|}
\hline ZIRLO & & & & & \\
\hline \multirow[t]{2}{*}{ At $500^{\circ} \mathrm{C}$} & $10 \mathrm{~h}$ & $24 \mathrm{~h}$ & $72 \mathrm{~h}$ & $168 \mathrm{~h}$ & $336 \mathrm{~h}$ \\
\hline & $2.08 \mu \mathrm{m}$ & $3.22 \mu \mathrm{m}$ & $5.58 \mu \mathrm{m}$ & $8.52 \mu \mathrm{m}$ & $12.05 \mu \mathrm{m}$ \\
\hline \multirow[t]{2}{*}{ For $10 \mathrm{~h}$} & At $400^{\circ} \mathrm{C}$ & At $500^{\circ} \mathrm{C}$ & At $600^{\circ} \mathrm{C}$ & At $700^{\circ} \mathrm{C}$ & \\
\hline & $0.32 \mu \mathrm{m}$ & $2.08 \mu \mathrm{m}$ & $11.85 \mu \mathrm{m}$ & $19.90 \mu \mathrm{m}$ & \\
\hline \multicolumn{6}{|l|}{ Zircaloy-4 } \\
\hline \multirow[t]{2}{*}{ At $500^{\circ} \mathrm{C}$} & $10 \mathrm{~h}$ & $24 \mathrm{~h}$ & $72 \mathrm{~h}$ & $168 \mathrm{~h}$ & $336 \mathrm{~h}$ \\
\hline & $1.76 \mu \mathrm{m}$ & $2.73 \mu \mathrm{m}$ & $4.72 \mu \mathrm{m}$ & $7.21 \mu \mathrm{m}$ & $10.20 \mu \mathrm{m}$ \\
\hline \multirow[t]{2}{*}{ For $10 \mathrm{~h}$} & At $400^{\circ} \mathrm{C}$ & At $500^{\circ} \mathrm{C}$ & At $600^{\circ} \mathrm{C}$ & At $700^{\circ} \mathrm{C}$ & \\
\hline & $0.33 \mu \mathrm{m}$ & $1.76 \mu \mathrm{m}$ & $18.59 \mu \mathrm{m}$ & $26.15 \mu \mathrm{m}$ & \\
\hline
\end{tabular}

are oxidized at $500^{\circ} \mathrm{C}$ for $72-168 \mathrm{~h}$. It might be natural to suspect the thickness of oxide layers as a reason for the reduced chlorination reaction rate. Previously, Natesan and Soppet reported air oxidation rate constants for Zircaloy-4, ZIRLO, and M5 alloys at various temperatures [14]. Oxide thickness values calculated using the values offered by Natesan and Soppet are listed Table 2. Here, it should be noted that the rate constant values for a pre-breakaway case were employed, because a breakaway (peeling-off of oxide layers) behavior was not observed in the samples of the present study. As shown in the table, the thickness of oxide layer was almost doubled when the oxidation time increased from 24 to $72 \mathrm{~h}$, and it is suggested that $5.6 \mu \mathrm{m}$ is thick enough to protect ZIRLO hulls from chlorine gas. A comparison between the ZIRLO and Zircaloy-4 hulls might be meaningful, and it was shown that, when oxidized at $500^{\circ} \mathrm{C}$, the ZIRLO hulls exhibit thicker oxide layers and a lower chlorination reaction rate than the Zircaloy-4 hulls.

The relationship between the oxidation conditions and chlorination reaction behavior was further investigated by employing the XPS technique. Fig. 2 shows the XPS measurement and deconvolution results of the ZIRLO hulls oxidized at $500^{\circ} \mathrm{C}$ for up to $336 \mathrm{~h}$. Detailed information of 


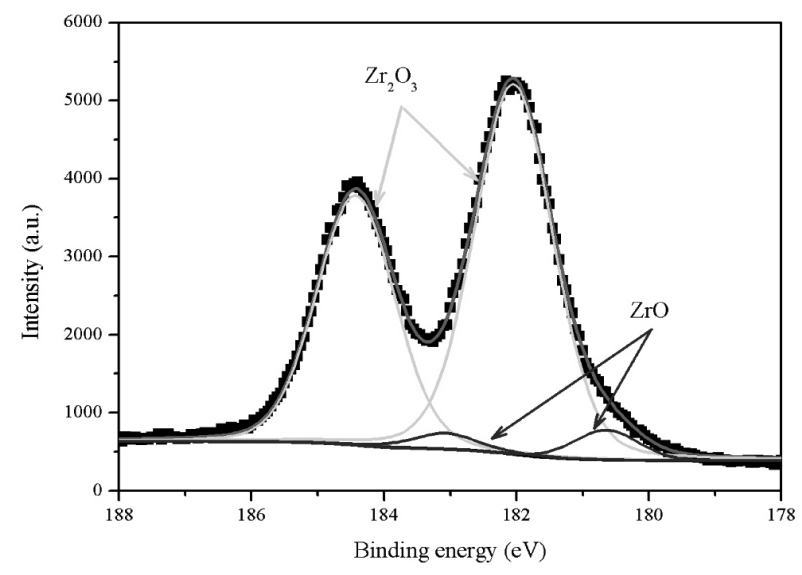

(a)

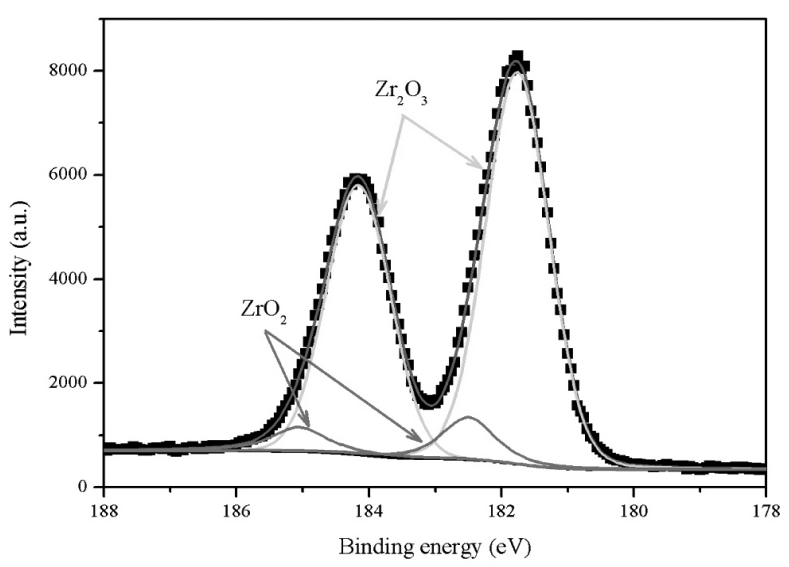

(c)

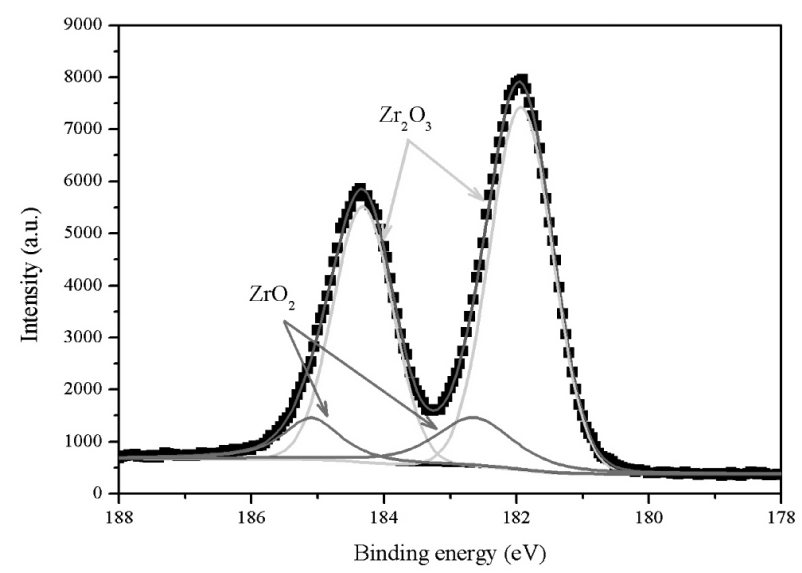

(e)

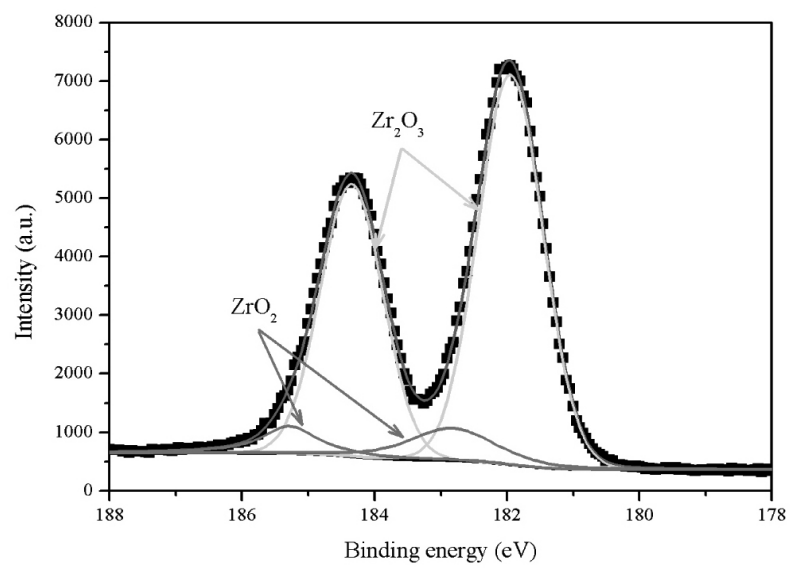

(b)

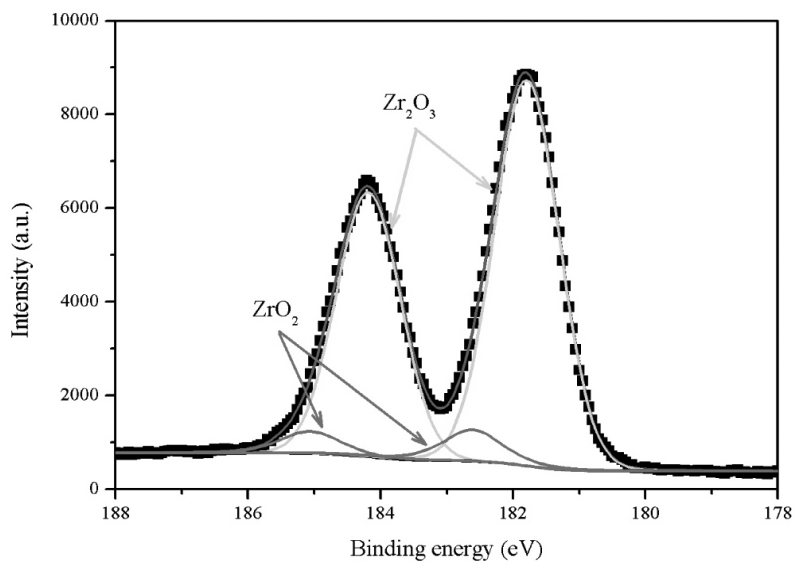

(d)

Fig. 2. The XPS measurement and deconvolution results for $\mathrm{Zr} 3 \mathrm{~d}_{5 / 2}$ peaks of the ZIRLO hulls oxidized at $500^{\circ} \mathrm{C}$ for (a) 10 , (b) 24 , (c) 72 , (d) 168 , and (e) $336 \mathrm{~h}$ under an air atmosphere. 
Table 3. The deconvolution calculation results of the XPS measurement results of the ZIRLO cladding hulls. The peak position of $\mathrm{Zr} 3 \mathrm{~d}_{5 / 2}$ peak is denoted, and ratio of each oxidation state was determined using the peak areas of $\mathrm{Zr} 3 \mathrm{~d}_{5 / 2}$ peaks

\begin{tabular}{|c|c|c|c|c|c|c|}
\hline Ox. temp & Dx. time & $\mathrm{ZrO}$ & $\mathrm{Zr}_{2} \mathrm{O}$ & & \multicolumn{2}{|c|}{$\mathrm{ZrO}_{2}$} \\
\hline $500^{\circ} \mathrm{C}$ & $10 \mathrm{~h}$ & $180.64 \mathrm{eV} \quad 5.68 \%$ & $182.04 \mathrm{eV}$ & $94.32 \%$ & & \\
\hline $500^{\circ} \mathrm{C}$ & $24 \mathrm{~h}$ & & $181.95 \mathrm{eV}$ & $88.14 \%$ & $182.83 \mathrm{eV}$ & $11.86 \%$ \\
\hline $500^{\circ} \mathrm{C}$ & $72 \mathrm{~h}$ & & $181.76 \mathrm{eV}$ & $90.14 \%$ & $182.50 \mathrm{eV}$ & $9.86 \%$ \\
\hline $500^{\circ} \mathrm{C}$ & $168 \mathrm{~h}$ & & $181.79 \mathrm{eV}$ & $91.84 \%$ & $182.61 \mathrm{eV}$ & $8.16 \%$ \\
\hline $500^{\circ} \mathrm{C}$ & $336 \mathrm{~h}$ & & $181.93 \mathrm{eV}$ & $82.07 \%$ & $182.62 \mathrm{eV}$ & $17.93 \%$ \\
\hline $400^{\circ} \mathrm{C}$ & $10 \mathrm{~h}$ & & $182.15 \mathrm{eV}$ & $100 \%$ & & \\
\hline $500^{\circ} \mathrm{C}$ & $10 \mathrm{~h}$ & $180.64 \mathrm{eV} \quad 5.68 \%$ & $182.04 \mathrm{eV}$ & $94.32 \%$ & & \\
\hline $600^{\circ} \mathrm{C}$ & $10 \mathrm{~h}$ & $180.59 \mathrm{eV} \quad 8.31 \%$ & $181.93 \mathrm{eV}$ & $91.69 \%$ & & \\
\hline $700^{\circ} \mathrm{C}$ & $10 \mathrm{~h}$ & $180.85 \mathrm{eV} \quad 9.16 \%$ & $182.11 \mathrm{eV}$ & $81.42 \%$ & $183.46 \mathrm{eV}$ & $9.42 \%$ \\
\hline
\end{tabular}

the deconvolution calculation results are listed in Table 3. As shown in the Figure and Table, a small portion of $\mathrm{ZrO}$ phase was observed in the ZIRLO-500-10 sample, while the $\mathrm{Zr}_{2} \mathrm{O}_{3}$ phase was identified as the major component even when the oxidation time is increased up to $336 \mathrm{~h}$. Interestingly, the ratio of $\mathrm{ZrO}_{2}$ phase did not change significantly when the oxidation time increased from 24 to $168 \mathrm{~h}$ (11.86 - 8.16\%), but a meaningful increase was observed in the ZIRLO-500-336 sample (17.93\%). Recalling that ZIRLO-500-24 was reactive with chlorine gas while ZIRLO-500-72 was not, and that the ratio of $\mathrm{ZrO}_{2}$ phase was 11.86 and $9.86 \%$ for each sample, it is suggested that, in this case, the ratio of $\mathrm{ZrO}_{2}$ is not a key parameter that determines the chlorination reaction feasibility. This result is not in line with our previous results for the Zircaloy-4 hulls, where it was concluded that $\mathrm{ZrO}$ can provide a pathway for chlorine gas, while $\mathrm{Zr}_{2} \mathrm{O}_{3}$ and $\mathrm{ZrO}_{2}$ cannot [11]. However, the chlorination reaction result of ZIRLO-500-24 (35.3\% weight loss) shows that the chlorination reaction can proceed in the absence of $\mathrm{ZrO}$ when the thickness of the oxide layer is thin enough (about $3.22 \mu \mathrm{m}$ ). A gap in the reactivity between side walls and cutting edges should be considered,

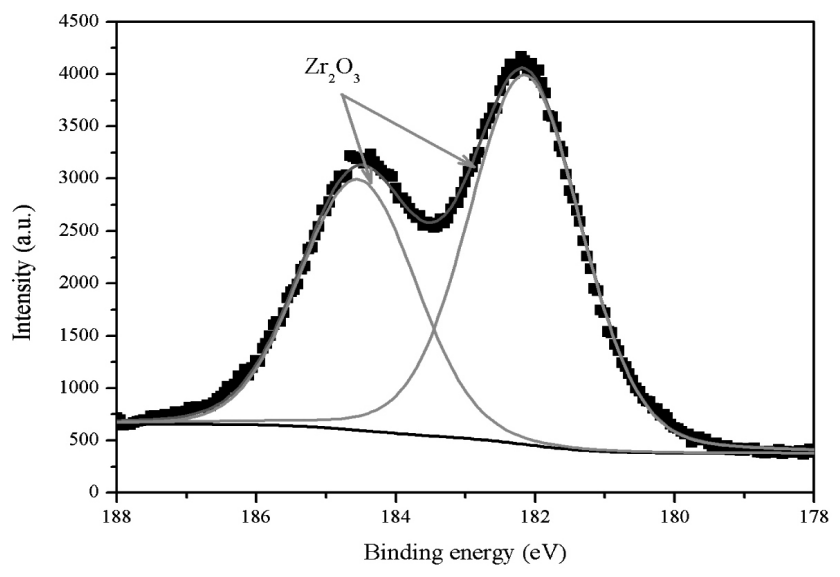

(a)

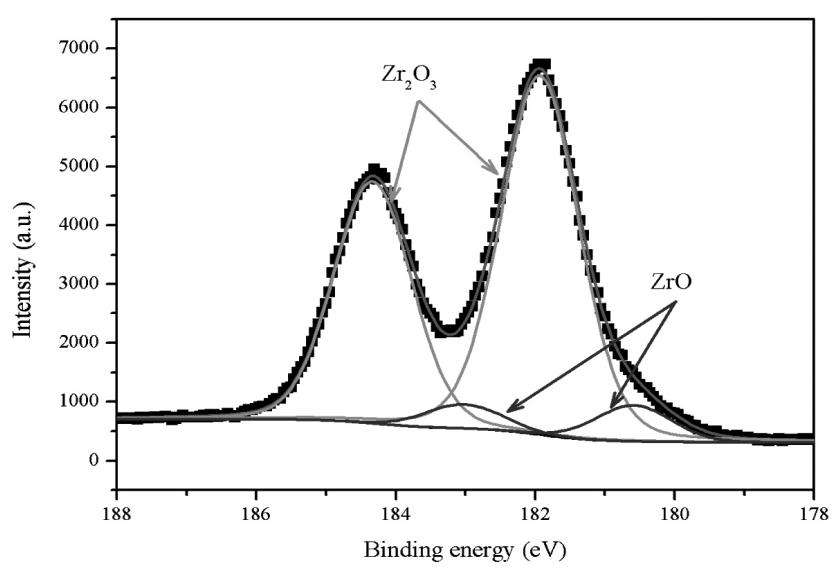

(b)

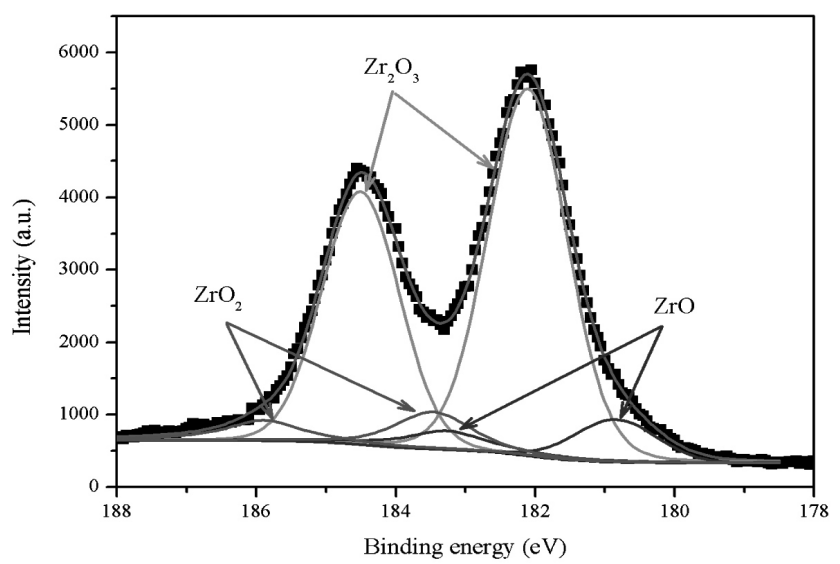

(c)

Fig. 3. The XPS measurement and deconvlution results for $\mathrm{Zr} 3 \mathrm{~d}_{5 / 2}$ peaks of the ZIRLO hulls oxidized at (a) 400 , (b) 600 , and (c) $700^{\circ} \mathrm{C}$ for $10 \mathrm{~h}$ under an air atmosphere. 


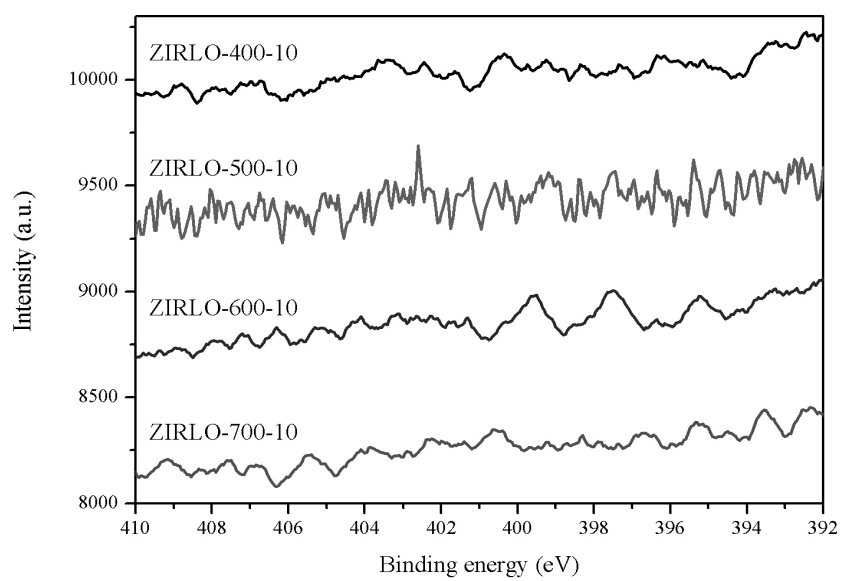

Fig. 4. The XPS measurement results of $\mathrm{N}$ 1s peaks of the ZIRLO hulls oxidized at $400,500,600$, and $700^{\circ} \mathrm{C}$ for $10 \mathrm{~h}$ under an air atmosphere.

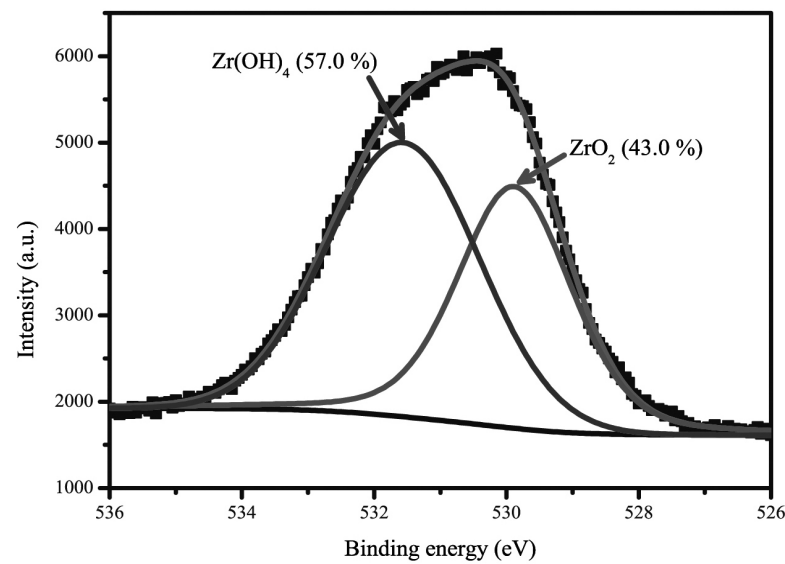

(a)

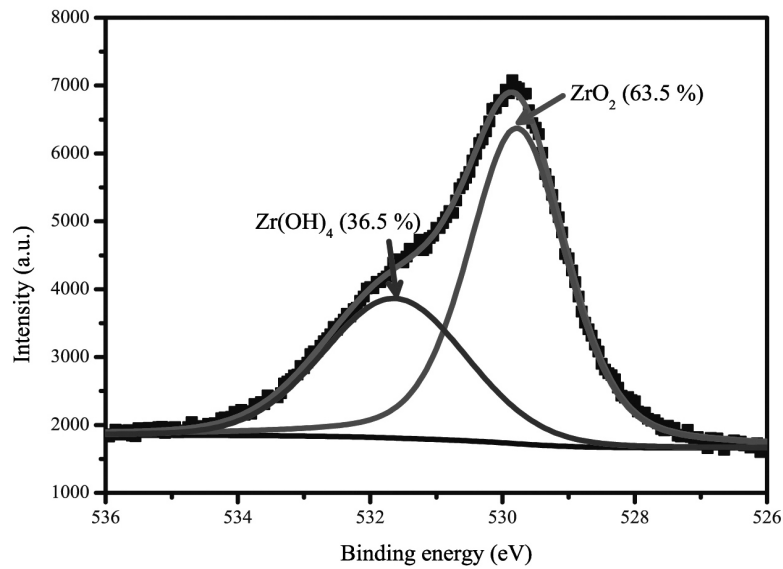

(c) because the XPS results represent the oxidation status of side walls while the chlorination reaction prefers cutting edges [15]. The photograph of ZIRLO-500-24 shown in ref. [12] can give a hint on this issue, because some holes are clearly shown on the side wall of the reaction residue proving that chlorine gas was reactive with ZIRLO-500-24 along the side wall. Thus, it can be concluded that, for the chlorination reaction, the thickness of the oxide layer is a key parameter as is the surface oxidation status.

The effect of oxidation temperature on the surface oxidation status was also investigated using the XPS technique, and the deconvolution results are shown in Fig. 3. Detailed information of the deconvolution results are listed Table 3.

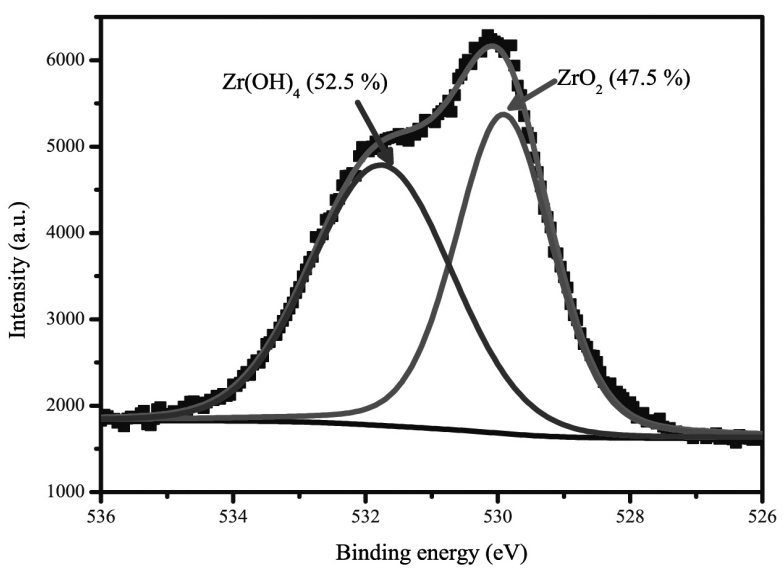

(b)

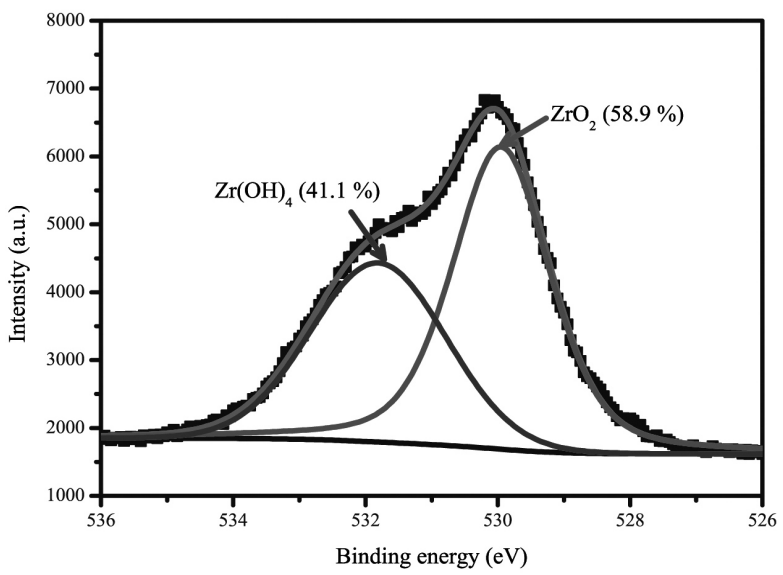

(d)

Fig. 5. The XPS measurement and deconvolution results for O 1s peaks of the ZIRLO hulls oxidizied at (a) 400, (b) 500, (c) 600, and (d) $700^{\circ} \mathrm{C}$ for $10 \mathrm{~h}$ under an air atmosphere. 
First, it is interesting to observe that the ratio of $\mathrm{ZrO}$ increases with an increase in the oxidation temperature: at $400^{\circ} \mathrm{C}$, no signs of $\mathrm{ZrO}$ were observed while the portion of $\mathrm{ZrO}$ increased up to $9.16 \%$ in ZIRLO-700-10. As shown in the Zircaloy-4 hulls [11], it was expected that the portion of $\mathrm{ZrO}$ decreases while that of $\mathrm{ZrO}_{2}$ increases with an increase in the oxidation temperature. However, the XPS results revealed an opposite results, and the ratio of $\mathrm{ZrO}_{2}$ was only $9.42 \%$ for ZIRLO-700-10, which was $28.6-32.7 \%$ in Zicaloy-700-5 [11]. This result was further studied by analyzing the XPS signals of nitrogen, because it was reported that oxidizing the ZIRLO hulls under an air atmosphere could produce a ZrN phase $[16,17]$. Fig. 4 shows the XPS measurement results for nitrogen 1s peak, and clearly, no signs of nitrogen are noticeable in all samples. Thus, the possibility was eliminated that the increased ratio of $\mathrm{ZrO}$ with increasing oxidation temperature might have come from the formation of the $\mathrm{ZrN}$ phase. The formation of zirconium hydroxide such as $\mathrm{Zr}(\mathrm{OH})_{4}$ instead of $\mathrm{ZrO}$ was also suspected, because the oxidation experiments did not employ dry air, leaving room for a reaction between zirconium and water. The XPS measurement and deconvolution results for the oxygen 1s peak are shown in Fig. 5. Generally, the XPS peaks of oxygen in a zirconium compound have two positions: one from $\mathrm{ZrO}_{2}$ (at $530.0 \mathrm{eV}$ ) and the other from $\mathrm{Zr}(\mathrm{OH})_{4}$ (at $531.2 \mathrm{eV}$ ) $[18,19]$. The deconvolution results revealed that the ratio of $\mathrm{ZrO}_{2}$ increased with an increase in the oxidation temperature, but it should be noted that a significant portion $(41.1 \%)$ of oxygen is still remaining in its hydroxide form even after oxidation at $700^{\circ} \mathrm{C}$. Thus, it can be suggested that the increase in $\mathrm{ZrO}$ ratio with increasing oxidation temperature came from the formation of the $\mathrm{Zr}(\mathrm{OH})_{4}$ phase. This result also suggests that the reaction between $\mathrm{Zr}$ and water included in the air is significantly accelerated at higher temperatures to produce Zr hydroxides.

\section{Conclusions}

The XPS results revealed that increasing the oxidation time at $500^{\circ} \mathrm{C}$ produces a greater $\mathrm{ZrO}_{2}$ phase, although the relationship between oxidation time and $\mathrm{ZrO}_{2}$ ratio is not linear. It was also shown that the chlorination reaction can proceed without a $\mathrm{ZrO}$ phase when the oxide layer is thin enough (around $3.2 \mu \mathrm{m}$ ), meaning that the oxide layer thickness should be considered as a key parameter during the hull chlorination process. The effect of oxidation temperature was also investigated, and it was shown that the ratio of $\mathrm{ZrO}$ increased from 0 to 5.68, 8.31, and 9.16\% when the ZIRLO hulls were oxidized at $400,500,600$, and $700^{\circ} \mathrm{C}$ for $10 \mathrm{~h}$, respectively. The possibility of a $\mathrm{ZrN}$ phase formation was eliminated owing to a lack of nitrogen peaks in the XPS measurement results. The XPS peak analysis on the $\mathrm{O}$ $1 \mathrm{~s}$ peaks revealed that $41.1 \%$ of oxygen is still remaining in its hydroxide form even in the ZIRLO-700-10 sample, suggesting that the increased $\mathrm{ZrO}$ ratio might have come from a formation of $\mathrm{Zr}$ hydroxide forms such as $\mathrm{Zr}(\mathrm{OH})_{4}$.

\section{Acknowledgements}

This work was sponsored by the Nuclear R\&D program of the Korean Ministry of Science, ICT \& Future Planning (No. 2012M2A8A5025802).

\section{REFERENCES}

[1] E.D. Collins, G.D. DelCul, B.B. Spencer, R.R. Brunson, J.A. Johnson, D.S. Terekhov, and N.V. Emmanuel, "Process Development Studies for Zirconium Recovery/Recycle from Used Nuclear Fuel Cladding”, Proc. Chem., 7(1), pp. $72-76$ (2012).

[2] M.K. Jeon, C.J. Park, C.H. Lee, K.H. Kang, and G.I. Park, "Simulation of radioactivation and chlorination reaction behavior for Zircaloy-4 and Zirlo cladding hull wastes”, J. Radioanal. Nucl. Chem., 292(3), pp. 12211228 (2012). 
[3] T.S. Rudisill, "Decontamination of Zircaloy cladding hulls from spent nuclear fuel", J. Nucl. Mater., 385(1), pp. 193-195 (2009).

[4] I.H. Jung, J.M. Shin, H.H. Lee, J.J. Park, and M.S. Yang, "Investigation of PWR Hull with a View to Downgrade", Sep. Sci. Tech., 41(10), pp.2097-2109 (2006).

[5] M.K. Jeon, C.H. Lee, C.J. Park, J.H. Choi, I.H. Cho, K.H. Kang, H.S. Park, and G.I. Park, "Effect of burn-up on the radioactivation behavior of cladding hull materials studied using the ORIGEN-S code", J. Radioanal. Nucl. Chem., 298(3), pp. 1629-1633 (2014).

[6] R. Fujita, H. Nakamura, K. Mizuguchi, M. Sato, T. Shibano, Y. Ito, T. Goto, T. Terai, and S. Ogawa, “Zirconium Recovery Process for Spent Zircaloy Components from Light Water Reactor (LWR) by Electrorefining in Molten Salts”, Electrochem., 73(8), pp. 751-753 (2005).

[7] C.H. Lee, K.H. Kang, M.K. Jeon, C.M. Heo, and Y.L. Lee, "Electrorefining of Zirconium from Zircaloy-4 Cladding Hulls in LiCl-KCl Molten Salts”, J. Electrochem. Soc., 159(8), pp. D463-D468 (2012).

[8] C.H. Lee, Y.L. Lee, M.K. Jeon, Y.T. Choi, K.H. Kang, and G.I. Park, "Effects of pretreatment processes for $\mathrm{Zr}$ electrorefining of oxidized Zircaloy-4 cladding tubes", J. Nucl. Mater., 449(1-3), pp. 93-100 (2014).

[9] Y. Yasuike, S. Iwasa, K. Suzuki, H. Kobayashi, O. Amano, and N. Sato, "Recycle of $\mathrm{Zr}$ metal from hull wastes by treatment of chlorination and metallization", Proc. ICEM'03: The $9^{\text {th }}$ International Conference on Radioactive Waste Management and Environmental Remediation, ICEM03-4626, September 21-25, 2003, Oxford, England.

[10] M.K. Jeon, K.H. Kang, G.I. Park, and Y.S. Lee, "Chlorination reaction behavior of Zircaloy-4 hulls: experimental and theoretical approaches", J. Radioanal. Nucl. Chem., 292(2), pp. 513-517 (2012).

[11] M.K. Jeon, K.H. Kang, C.M. Heo, J.H. Yang, C.H. Lee, and G.I. Park, "Effect of oxidation conditions on chlorination reaction of Zircaloy-4 hulls", J. Nucl. Mater., 424(1-3), pp. 153-157 (2012).
[12] M.K. Jeon, Y.T. Choi, C.H. Lee, Y.L. Lee, K.H. Kang, and G.I. Park, "Effect of Oxidation Process on the Reaction Kinetics of Zirlo Chlorination Reaction", Trans. Am. Nucl. Soc., 108(1), pp.163-164 (2013).

[13] R.W.M. Kwok. XPS peak fitting program for WIN95/98 XPSPEAK version 4.1, Department of Chemistry, The Chinese University of Hong Kong, Shatin, Hong Kong (2000).

[14] K. Natesan and W. K. Soppet. Air Oxidation Kinetics for Zr-Based Alloys, Argonne National Laboratory, NUREG/Cr-6846, ANL-03/32, USA (2004).

[15] M.K. Jeon, C.H. Lee, C.M. Heo, Y.L. Lee, Y.T. Choi, K.H. Kang, and G.I. Park, "Chlorination Reaction Behavior of Zircaloy-4 Hulls: A Preliminary Study on the Effect of the Oxidation Process on the Reaction Rate”, J. Korean Radioact. Waste Soc., 11(1), pp.6975 (2013).

[16] C. Duriez, D. Drouan, and G. Pouzadoux, "Reaction in air and in nitrogen of pre-oxidised Zircaloy-4 and M5 ${ }^{\text {TM }}$ claddings", J. Nucl. Mater., 441(1-3), pp. 84-95 (2013).

[17] M. Steinbrück and M. Böttcher, "Air oxidation of Zircaloy-4, M5 ${ }^{\circledR}$ and ZIRLO $^{\mathrm{TM}}$ cladding alloys at high temperatures", J. Nucl. Mater., 414(2), pp.276-285 (2011).

[18] D.Q. Peng, X.D. Bai, F. Pan, H. Sun, and B.S. Chen, "Influence of aluminum ions implanted on oxidation behavior of ZIRLO alloys at $500^{\circ} \mathrm{C}$ ", Vacuum, 80(6), pp.530-536 (2006).

[19] Y. Nishino, A.R. Krauss, Y. Lin, and D.M. Gruen, "Initial oxidation of zirconium and Zircaloy-2 with oxygen and water vapor at room temperature", J. Nucl. Mater., 228(3), pp.346-353 (1996). 